九州大学学術情報リポジトリ

Kyushu University Institutional Repository

\title{
Equity, Efficiency and Farmland System in China
}

Chen, Tinggui

College of Economics and Management, Shanghai Ocean University

Chen, Linsheng

College of Economics and Management, Shanghai Ocean University

Yokogawa, Hiroshi

Faculty of Economics, Kyushu Kyoritsu University

Yabe, Mitsuyasu

Laboratory of Environmental Life Economics, Department of Agricultural and Resource Economics, Faculty of Agriculture, Kyushu University

https://doi.org/10.5109/20342

出版情報: 九州大学大学院農学研究院紀要. 56 (2)，pp.431-438，2011-09. Faculty of Agriculture， Kyushu University

バージョン :

権利関係 : 


\title{
Equity, Efficiency and Farmland System in China

\author{
Tinggui CHEN ${ }^{1}$, Linsheng CHEN $^{1}$, Hiroshi YOKOGAWA ${ }^{2}$ \\ and Mitsuyasu YABE ${ }^{3 *}$
}

\author{
Laboratory of Environmental Life Economics, Department of Agricultural and \\ Resource Economics, Faculty of Agriculture, Kyushu University, \\ Fukuoka 812-8581, Japan \\ (Received April 30, 2011 and accepted May 9, 2011)
}

\begin{abstract}
Equity and efficiency are often in contradictory, but sometimes can have both. The evolution of institutional arrangements of farmland in the People's Republic China (the PRC) in 60 years also confirmed this theory. Land reform and the household responsibility system of farmland make farmers to obtain land use right equally, it is also realized the tremendous increase in agricultural productivity. Policy goals of equity and efficiency are in synchronization. In the period of agricultural co-operation, farmers do not have property right of farmland, this achieve near-absolute equity. Because of the loss of farmland ownership, farmers lose the enthusiasm for production. Agricultural productivity is badly lowed. In the pursuit of equity efficiency lost. Because of the dual economic structure and level of economic development, the goal of China's farmland policy which is giving priority to equity with the consideration to efficiency, will remain a long time in the future.
\end{abstract}

Key Words: property right, use right, farmland transfer

\section{INTRODUCTION}

China's GDP reached 5.83 trillion U.S. dollars in 2010 (Yu, 2011) surpassing Japan as the world's second largest economy. Shouted by the world that China has entered the ranks of developed countries today, the government and many scholars have insisted that China is still a developing country, the most important reason is that per capita GDP is very low, according to World Bank statistics, China's per capita GDP was \$ 3,744 in 2009, ranked No. 106 in the world, representing 44\% of the world average, $10 \%$ of high-income countries' average, China is still a lower middle-income country. One of the important reasons for low per capita GDP is the differences of income between urban and rural area, rural per capita income was $\$ 758$ in 2009 , only $30 \%$ of $\$ 2,526$ per capita income of urban residents (the exchange rate of $\mathrm{U}$. S. dollar and the RMB is 100:680). 30 years of reform and opening up, the rural population reduced from $82 \%$ in 1978 to $53 \%$ of the national population in 2009. However, because of the population increase, the total rural population decreases from 79,014 in 1978 to 71,288 in 2009, less than 10\% (China Statistical Yearbook, 2010). The problems of China's agriculture, rural areas and farmers (Three Rural Issues) are still not resolved, as the rapid growth of GDP. The problem of farmland is the fundamental problem in all the Three Rural Issues. Some scholars pointed out that private ownership of farmland is the fundamental approach to solve the current Three

${ }^{1}$ College of Economics and Management, Shanghai Ocean University, Shanghai, China

${ }^{2}$ Faculty of Economics, Kyushu Kyoritsu University, Fukuoka, Japan

${ }^{3}$ Laboratory of Environmental Life Economics, Department of Agricultural and Resource Economics, Faculty of Agriculture, Kyushu University, Fukuoka, Japan

* Corresponding author (E-mail: yabe@agr.kyushu-u.ac.jp)
Rural Issues (Chen, 2010). Restrictions by the Chinese political system, the implementation of private ownership of farmland is highly unlikely, so under the premise of the existing collective ownership of farmland, promoting the transfer of the use right of contracted farmland, improving agricultural productivity is particularly important.

The transfer of the use right of contracted farmland, on the one hand can make land to be transferred to more productive land-users and improve productivity. On the other hand, it has facilitated the low skill farm producers to transfer to non-farm sector, as to increase rural incomes in two ways. The focus of the policy of the transfer of the use right of contracted farmland is on efficiency. In addition, in the second round of the 30-year land contract period, the policy to promote "people increase do not increase land, people decrease do not decrease land" is the result of focusing the importance of efficiency. The transfer of the use right of contracted farmland is to increase agricultural productivity, and can achieve a better income distribution of the farmers in agriculture and other industries. However, especially in relation to the transfers of the use right of contracted farmland that the rural collective economic organizations recovery the right of land contract will bring the unfair distribution of farm income problem. Even in today's economic level, farmland system in China still has social security and unemployment insurance functions. Whether owning equally farmland use right is a problem of equity that can affect the social stability.

The studies on the transfers of the use right of contracted farmland in China can be divided into three categories: The first is the study of the way and development status of farmland transfer, including Jia et al. (2003), Zhang et al. (2007), Zhao (2008), and Ye (2006). The second is about the motivation of farmland transfer, including Jia (2003), Wen et al. (2007) and Chan (2008). 
The third category is to the effect on the farmland transfer, including Tian (2005), China Rural Land System Research Group (2006), Jin and Klaus (2004). China Rural Land System Research Group (2006) uses functional structure methods comparing study the equity and efficiency of three categories of farmland transfer methods, the land equalization policy, the two field system, and the auction of wasteland system. The research group believes that he farmland system reform should continue to adhere to the principle of giving priority to efficiency. Jin and Klaus (2004) gives a detailed analysis to the status of farmland rental markets, farmland rental market development and the effects to equity and efficiency of three provinces of southwest China. The study found that to transfer land among farmers at farmland rental markets has become the main form of farmland transfer. The transfers at farmland rental markets are important than the farmland transfers by administrative redistribution. Although farmland rental markets and farmland redistribution would bring the farmland to transfer to the farmers who owned less endowment of farmland, the farmland rental market can enhance productivity. These studies mainly analyze the equity and efficiency of farmland use right transfer, and do not analyze the equity and efficiency of the legal system of farmland use right transfer itself. Qi and Shi (2008) uses nine litigations of farmland use right disputes as examples to research the standardization level of contractual farmland transfer, the reasons for disputes, achieving rates of the plaintiff's demands and results of the implementation. But the study did not involve equity and efficiency.

For these reasons, this paper will analyze the evolution of the farmland system of China from the perspective of equity and efficiency. Firstly, an equity and efficient theoretical framework of economic analysis has been built. Secondly, use this theoretical framework to analyze the equity and efficiency of the evolution of farmland system of China. Thirdly, through a few cases of disputes in litigation about the transfers of the use right of contracted farmland in Chongqing city, analyze the policy direction in the equity and efficiency of farmland system in China. Finally, combine with China's current level of economic development and political system, look the future policy orientation on equity and efficiency of farmland system.

\section{THEORETICAL ASSUMPTIONS AND ANALYTICAL FRAMEWORK}

The equity in this paper means equitable distribution, including the distribution of farmland and agricultural property income distribution. Efficiency refers to optimal allocation of resources to achieve higher productivity. Economists say equity and efficiency are sometimes mutually reinforcing. However, in most cases, the two are often conflicting. Pursuit of higher efficiency need a greater degree of inequity as a cost; to promote equity, it must damage more efficiently. People often have to face a difficult choice: "higher efficiency, or a greater degree of equity?" How to balance between the two and to find the optimal combination of different conditions are main task of economists.

The contradiction between equity and efficiency can be illustrated in two ways. First of all, equity is not necessarily conducive to enhancing efficiency. With the improvement of distribution, economic efficiency may increase or decline. Efficiency increase does not necessarily mean a equity increase. Along with efficiency increase, income distribution may improve, remain the same, or even worse.

The farmland has the dual nature of resources and assets. If the farmland looks as an essential carrier of agricultural production, it is resources, the rational allocation should be optimized to improve land and labor productivity. If we think about the property right and use right as well as its output, farmland is an asset, which involves the allocation and the issue of equity.

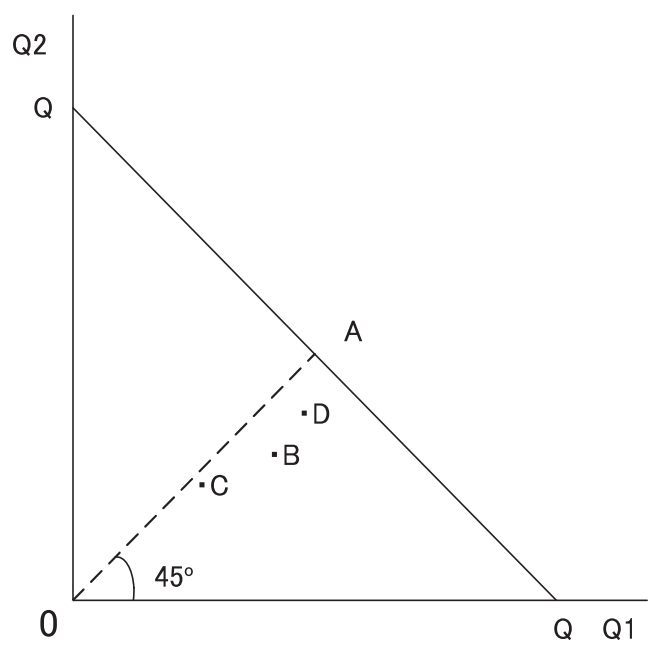

Fig. 1. Analysis model of equity and efficiency of farmland system.

We constructed the theoretical model shown in Fig. 1, and made the following assumptions:

- Only two members of the community, the capital including cattle, farm machinery and the labor resources which the first member owns are more than the second.

- The amount of farmland is constant.

- The agricultural production techniques remain unchanged.

- The farmland system is variable.

- The maximum output of farmland is Q.

Horizontal axis and vertical axis respectively represent the two members' output $\mathrm{Q}_{1}, \mathrm{Q}_{2}$, those are also their incomes. QQ curves is the production possibility frontier, subject to resource constraints, the points outside the curve can not be achieved, the points curves within is possible, the points in the QQ curve is maximum output Q. Any point on QQ curve is the most efficient point, and there is $\mathrm{Q}_{1}+\mathrm{Q}_{2}=\mathrm{Q}$. $\mathrm{Q}$ is distributed between the two members. There is a variety of distribution methods, distributed in all points within the triangle OQQ (includ- 
ing the points on three edge), and any point on the 45 degree line $\mathrm{OA}$ is the most equity point of distribution. Because $\mathrm{Q}$ can be converted to farmland area, the distribution of $\mathrm{Q}$ can be looked as the distribution of farmland property right and use right which is implemented by farmland area.

\section{THE EVOLUTION OF EQUITY AND EFFICIENCY OF LAND SYSTEM OF THE PRC}

According to the differences of farmland property right and use right, the evolution of farmland system can be divided into three stages: land reform, agricultural Cooperation and household responsibility system (Table 1).

One of the most important reasons that the Chinese Communists could defeat the KMT regime, is the success of land reform. At the stage of land reform, farmland occupied by the landlord was distributed to farmers without any payment. Farmland is privately owned, property right of farmland, use right and output distribution righs belong to farmers. Table 2 shows the results of this reform is all sectors of society get farmland almost equally. To the farmers, the reform is the realization of egalitarianism, the equity policy is unprecedented. Under this system, the distribution of property right and use right is on the OA line, farmers get an equal farmland right. Farmers' desire to production was unprecedented, land reform significantly improved productivity. From 1950 to 1952, the average annual rate of increase of food (the definition of grain in China references Tinggui Chen, Mitsuyasu Yabe, 2009), oil crops (peanuts, rapeseed, sesame, sunflower seeds, etc.), cotton production reached a 13.1\%, 17.8\%, 43.2\% (Zhang, 2002). At constraints of technology at that time, production external moved close to QQ line, reaching a high efficiency. This design of the farmland system acquired two policy objectives of equity and efficiency, a win-win results. Despite the equal distribution of farmland right, due to the first member owned more non-farmland resource endowment than the second member, agricultural output $Q_{1}$ was slightly larger than $Q_{2}$. The results can be illustrated in point B of Figure 1.

At the end of farmland reform in 1953, China began the socialist transformation of agriculture at the purpose of mutual assistance and cooperation. Agricultural cooperation can be divided into two phases: mutual aid and primary stages of agricultural production cooperatives, and the senior stage of agricultural production cooperatives and communes. In the first phase, to maintain farmland private property right, collective management of agriculture began, and allocate the output according to the ratio of capital which is the resources of farmers in agricultural production. This institutional arrangement is based on respect for farmers' will, solve the problem that a part of farmers lack of tools, and to some extent achieve economies of scale, thereby improve the production efficiency. Keeping the equity of farmland reform, agricultural production further close to the QQ line to achieving greater efficiency at this period.

Senior agricultural production cooperatives reform which began at 1956, abolished allocation of output by the ratio of capital. Farmland privately owned by the farmers changed into owned by the collective public. Based on the senior agricultural production cooperatives, commune was established in 1958, thus forming a collective ownership of farmland. This system had a threegrade-organization: commune, production brigade and

Table 1. The evolution of China's farmland property right and use right

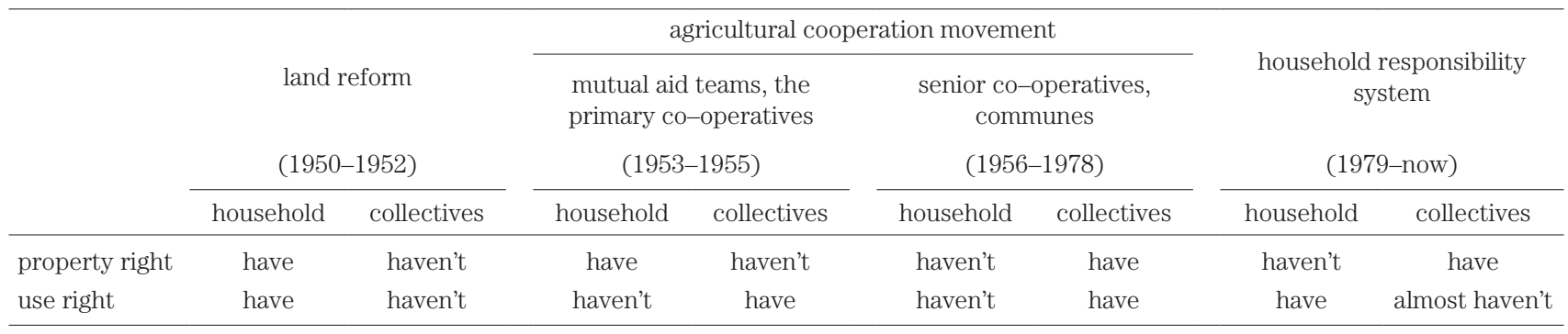

Source: collected by author

Table 2. Ownership of arable land of all classes after the land reform (1954)

\begin{tabular}{lccc}
\hline & the proportion of the population & the proportion of arable land & possession of arable land per household \\
\hline & $\%$ & $\%$ & Mu \\
poor peasants & 52.2 & 47.1 & 12.46 \\
middle peasants & 39.9 & 44.3 & 6.4 \\
rich peasants & 5.3 & 2.2 & 25.09 \\
landlord & 2.6 & 100 & 12.16 \\
total & 100 & - \\
\hline
\end{tabular}

Source: China Statistical Yearbook of Rural Economy (1989), cited in Liu Rongcai (2010).

Note: the criteria for the classification on the poor peasants, rich peasants, landlords and other classes, please refer to Chen (2009). 
production team, the production team was the basic operating units, referred to as "three-level-owned, teambased." In the commune system, farmland was owned and operated by the collectives, households were no longer the independent business units. Farmers were only members of the collective, their output were allocated by the production team, brigade or commune in accordance with the rules of the state. This institutional arrangement did not fit the development of rural areas, went against the wishes and requirements of farmers. Farmers' production enthusiasm had been greatly inhibited. The costs of supervision of agricultural production and management costs of the organization were very high. Household income was very low. This leaded to even the farmer's basic living was not guaranteed in many parts of China.

Though the total grain output reached 200 million tons in 1958, then decreased all the way, and returned to 214 million tons until 1966, reached 305 million tons in 1978, the annual average growth rate is only $2.6 \%$. From 1958 to 1978, oil crops production increased from 4.77 to 5.22 million tons, the annual average growth rate is only $0.5 \%$. Cotton production increased from 1.969 to 2.098 million tons, the annual average growth rate is just $0.3 \%$. Low food production growth combined with rapid population growth, from 1957 to 1978 the agricultural population per capita food production decreased from $85.05 \mathrm{~kg}$ to $62.6 \mathrm{~kg}$, cotton decreased from $2.65 \mathrm{~kg}$ to $2.6 \mathrm{~kg}$, edible oil reduced from $1.95 \mathrm{~kg}$ to $1.1 \mathrm{~kg}$ (Zhang 2002 and China Statistical Yearbook 2006). The supply of agricultural products is in extreme shortage, almost all agricultural products were allocated through the distribution system.

The above analysis indicates that under the arrangement of the people's commune system, farmland property right, use right and distribution right belong to the collective, farmers have no any right. Agricultural products are unified distributed. This realized the highest degree of equity. However, due to household income does not proportional to the labor, coupled with high costs of agricultural production supervision and organization operating costs, productivity was extremely low. Agricultural production moved to point O. The institutional arrangements of the equity and efficiency can be illustrated by point $\mathrm{C}$ in Figure 1.

People's commune system led disastrous consequences in the national economy and national life, not only the rural community, the national economy as a whole fell into the brink of collapse. At this background, China has implemented household responsibility system since 1978, represented by a series of agricultural production and marketing reform, which is the third time farmland reform since the founding of the PRC.

The household responsibility system which began in 1978, on the condition of maintaining the collective ownership of farm land, allocated the use right of farmland equally to the group members to ensure equity. The distribution of agricultural output was in accordance with "pay enough for the state, leave enough for the collective, leave behind their own", so that farmers got part of the distribution right of agricultural output. The equity of this system also brought a highly efficient agricultural production, farmers unprecedented burst of passion, the production is rapidly increasing, the problem of food supply shortage by a large degree had been relieved. From 1979 to 1984, grain production increased by $6.2 \%$ on average, the total output from 300 million tons to 400 million tons. The annual average growth rate of cotton and oil crops are $19.3 \%$ and $14.7 \%$ respectively (Chinese Ministry of Agriculture, 1996). that between 1978 and 1984, gross agricultural output in China increased by $42.23 \%$ in constant prices, of which approximately half (46.89\%) come from increased productivity by the household responsibility system reform (Lin, 1992). The agricultural total factor productivity of China increased by 20\% from 1980 to 1984 (General Project Group of Development Research Institute, 1988). Thus, the early stages of the household responsibility system is to ensure the equity and also achieve policy objective of improving efficiency. This institutional arrangement of the equity and efficiency can be illustrated by point D in Fig. 1 .

However, with increasing of agricultural production, the new system began to show the limitations, too small scale of operation and too fragmented land structure seriously affected labor productivity, and limited the increase in the income of farmers. That is, the equity system of farmland had been showing lack of efficiency. To this end, promote the transfer of farmland to expand the scale of operation has become urgent and inevitable.

As a national policy, to promote transfer of farmland started in 1984, "a number of policy measures on the current agricultural and rural economic development" published in 1993 pointed out clearly that on the condition of farmland collective ownership and farmland use does not change the subject, under the agreement of the owner, use right of land is allowed to transfer with compensation according to law. The Sixteenth National Congress of China in 2002 proposed that under the principles of in accordance with law, voluntary and compensatory, contracted use right of farmland can be transferred, and gradually develop scale operation. Implemented in 2003, Rural Land Contract Law clearly defined the principles, duration, fees, methods and contracts on the transfer of use right of farmland. Property Law reaffirmed the Rural Land Contract Law on the farmland use right transfer, and defined the land use right as property, to further strengthen the protection the right of farmers in 2007. Third Plenary Session of the 17th "CPC Central Committee resolution in 2008 on rural reform, development of a number of major issues" that strengthen the contracted farmland right management and services, establish and improve the market for transferring farmland contract and management right, in accordance with the law of voluntary and compensatory basis, Allow farmers to subcontract, lease, exchange, transfer, stock transfer and other forms of couse right to land contractual management, the development of various forms of appropriate scale. CPC Central Committee and the State by the above measures continue to enrich the contents of the household resposibility system and 
promote farmland transfer, promote scale.

However, agricultural taxes exemption and agricultural subsidies began in 2006 reduced operating costs in agriculture, to some extent hindered the transfer of farmland use right. Free farmland transfer and transfer by subsidizing the cost taken place before encountered new problems, many who turn out want to recover farmland use right. Prices of agricultural products increased in the second half of 2007, the economic downturn in 2008 led to loss of work opportunities, a large number of returning migrant workers, which have turn out their farmland want to recover their contracted farmland, some led to civil disputes even legal proceedings.

\section{ANALYSIS ON THE TRANSFER OF FARM LAND USE RIGHT COURT CASES}

We have collected 5 court cases about the transfer of farm land use right which occurred in Chongqing city. Through the happening reasons, results and basis of judgment, we analyze the policy direction in the equity and efficiency of farmland system in China.

Shown in Table 3, all of the contracted period of five cases were 30 years, starting time was around in 1998, transfer started around in 2000. All except No. 3 case did not have transfer contract, all cases did not clearly define transfer deadline. The scale of transfer land per household range from 0.75 to $5.57 \mathrm{mu}$ (15 mu are equal to $1 \mathrm{ha}$ ). There are no rent for transferred farmland in three cases, the other two cases have very low rent, 200 and $150 \mathrm{~kg}$ paddy per mu per year respectively.

Table 4 summarizes the content and the demands of the five case verdict. Plaintiffs are all who contracted farmland use right, defendants are mostly farmland use right transferee, the defendants of case 5 also include tender side of contract, that is, the rural collective organization. Return the contracted land is the common requirement of all the plaintiffs, in addition, the plaintiffs asked to compensate the damages and recover the rent.

We need to focus on the basis for judgment and results for the case. All but case No. 5 win by the plaintiffs. Four cases win by plaintiff were based on Rural

Table 3. The basic situation of farmland transfer

\begin{tabular}{|c|c|c|c|c|c|}
\hline case no. & 1 & 2 & 3 & 4 & 5 \\
\hline contract period & $\begin{array}{l}\text { March } 1998 \text { to } \\
\text { February } 2028\end{array}$ & $\begin{array}{l}\text { October } 1998 \text { to } \\
\text { September } 2028\end{array}$ & $\begin{array}{c}\text { November } 1997 \text { to } \\
\text { October } 2027\end{array}$ & $\begin{array}{c}\text { June } 1998 \text { to May } \\
2028\end{array}$ & $\begin{array}{l}\text { January } 1999 \text { to } \\
\text { December } 2028\end{array}$ \\
\hline contract for transfer & haven't & haven't & have & haven't & haven't \\
\hline transfer time & 2000 & 2002 & 1998 & 2001 & 2001 \\
\hline transfer period & no agreement & no agreement & no agreement & no agreement & no agreement \\
\hline transfer area $(\mathrm{Mu})$ & 2.18 & 4.3 & 1.35 & 5.57 & 0.75 \\
\hline rent (kg rice/mu year) & haven't & 200 & haven't & haven't & 150 \\
\hline
\end{tabular}

source: collected by author.

Table 4. The appeals of the parties

\begin{tabular}{|c|c|c|c|c|c|}
\hline case no. & 1 & 2 & 3 & 4 & 5 \\
\hline time & 2006.3.20 & 2005.6 .12 & 2007.3.1 & 2008.8 .5 & 2008.10.6 \\
\hline plaintiff & contractor & contractor & contractor & contractor & contractor \\
\hline defendant & transferee & transferee & transferee & transferee & transfree, tender side \\
\hline demands for plaintiff & $\begin{array}{l}\text { return the farmland, } \\
\text { compensation for } \\
\text { the losses }\end{array}$ & $\begin{array}{l}\text { return the farmland, } \\
\text { ask for rent }\end{array}$ & $\begin{array}{l}\text { renturn the } \\
\text { farmland, } \\
\text { recover theland, } \\
\text { compensation for } \\
\text { the loss }\end{array}$ & return the farmland & $\begin{array}{l}\text { return the farmland, } \\
\text { pay } 5000 \text { yuan for } \\
\text { the loss }\end{array}$ \\
\hline demands for defendant & & & $\begin{array}{l}\text { dismissed the } \\
\text { plaintiff's appeal }\end{array}$ & & \\
\hline legal judgement & plaintif win & plaintif win & plaintif win & plaintif win & defendant win \\
\hline basis for judgement & $\begin{array}{l}\text { farmland contract } \\
\text { law, supreme } \\
\text { people's court on the } \\
\text { interpretation of law } \\
\text { application about } \\
\text { involving disputes } \\
\text { in the rural land } \\
\text { contract }\end{array}$ & $\begin{array}{l}\text { farmland contract } \\
\text { law, supreme } \\
\text { people's court on } \\
\text { the interpretation } \\
\text { of law application } \\
\text { about involving } \\
\text { disputes in the rural } \\
\text { land contract }\end{array}$ & $\begin{array}{l}\text { farmland contract } \\
\text { law, supreme } \\
\text { people's court on } \\
\text { the interpretation } \\
\text { of law application } \\
\text { about involving } \\
\text { disputes in the } \\
\text { rural land contract }\end{array}$ & $\begin{array}{l}\text { farmland contract } \\
\text { law, supreme } \\
\text { people's court on } \\
\text { the interpretation } \\
\text { of law application } \\
\text { about involving } \\
\text { disputes in the rural } \\
\text { land contract }\end{array}$ & $\begin{array}{l}\text { civil law, civil } \\
\text { evidence } \\
\text { requirements by the } \\
\text { supreme people's } \\
\text { court }\end{array}$ \\
\hline
\end{tabular}


Land Contract Law and "Supreme People's Court on the interpretation of law application about involving disputes in the farmland contract". The case win by the defendant was based on Civil Law and "Civil Evidence Requirements by the Supreme People's Court". Case 4 as an example, the specific basis for its decision is: The Court finds that the most general rule to identify the use right of farmland is the contractual use right certificate, the plaintiff holds the contractual use right certificate, so the plaintiff is still recognized enjoy the contractual use right of land. Though the defendant thinks that the plaintiff has returned his contracted farmland to the collective voluntarily, but he did not provide strong evidence. Because the twenty-ninth article of the Rural Land Contract Law specifies that "in the contract period, ...... the contractor who return contracted land voluntarily should provide written notice six months in advance to the tender side", and Article 10 of "Supreme People's Court on the interpretation of law application about involving disputes in the rural land contract" specifies that if the contractor does not meet the procedures of twenty-ninth article of the Rural Land Contract Law to return the farmland use right, it may not recognize as a voluntary return. It is precisely because the two defendants can not confirm the evidence that the plaintiff had provided written notice to the defendant (the tender side), the court can not conclude that plaintiffs voluntarily returned the land use right, so the excuse of the two defendants shall not be accepted.

The common features of these legal proceedings areas below:

- by the effects of non-farm income, age and living very far away from contractual farmland, the original contractor in fact can not cultivate his own contractal land.

- new cultivators have invested 5 to 10 years of labor to transform the land, or plant fruit trees and other perennial crops.

- the contractors wish to recover the original free or low-rent transferred farm land, charge the new cul-

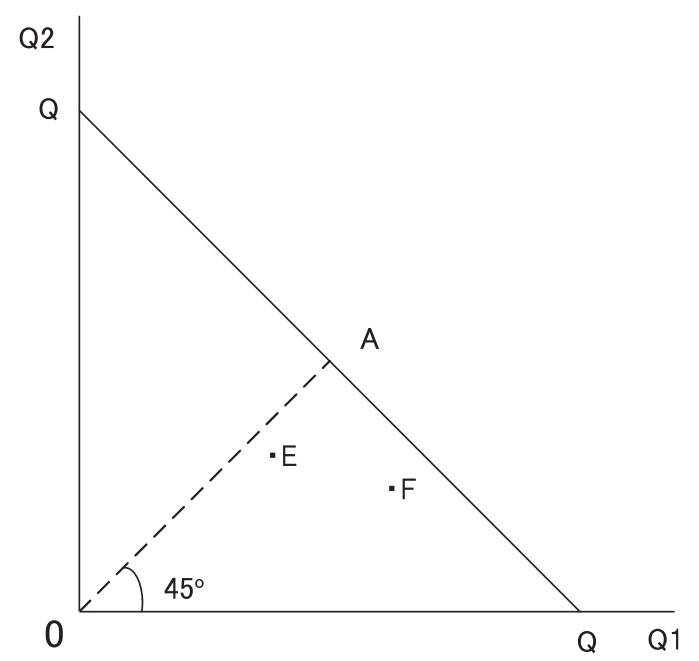

Fig. 2. Effects of farmland transfer and the court cases legal judgements on equity and efficiency. tivators and collective organizations as the defendants.

- In the context of existing laws and regulations, it is often in favor of the original land contractors. However, due to land attachments, especially the treatment of perennial crops, it is difficult to enforce judgments, this led to the land farming can not continue. This decision allows the contractor to recover the original land contractual use right, but severely damage the initiative of lessee of the transfer, this gives serious impact on land use efficiency.

If suppose agricultural income of the farmland contractor as $\mathrm{Q}_{2}$, the agricultural income of farmland transferee as $Q_{1}$, then the occurrence of transfer of farmland, and the results of these legal judgements on agricultural production efficiency and equity distribution of agricultural income can illustred in Fig. 2, the occurrence of transfer of farmland improves agricultural productivity, but reduces the equity distribution of agricultural income, from point $\mathrm{E}$ to point $\mathrm{F}$. The legal judgements of farmland transfer verdict litigation cases improve the equity distribution of agricultural income, but lower agricultural productivity, from point $\mathrm{F}$ back to point $\mathrm{E}$.

\section{CONCLUSIONS AND DISCUSSIONS}

The paper build an economic model on equity and efficience to analyze the farmland system since the founding of the PRC. We found that in the land reform, agricultural cooperatives and the household responsibility system, regardless the farmland property right belonged to farmers or the collective organization, farmland as an asset was allocated equally for all farmers. That is to say these systems are equity. In the phase of land reform, farmers had equal property right of farmland, use right and the right to dispose of agricultural income. In phase of the agricultural cooperatives, farmland property right, use right and the right to dispose of farm income were attributable to the collective organizations, farmers did not have any right associated with farmland, it is also equity. In the phase of the family responsibility system, the property right of farmland held by the collective organizations, farmland use rights are allocated to the peasants eqaully, the peasants firstly have half right to the distribution of agricultural income, then have full right to dispose the income. However, due to differences in resource endowments other than the farmland owned by farmers, agricultural income is not equally distributed to farmers. The extent of this inequity is least in the agricultural co-operative phase, are larger in the land reform and the household responsibility system phase.

Different right of farmland arrangements have huge impacts on efficiency of agricultural production. As obtained property right of farmland, land reform gave farmers unprecedented enthusiasm for production, greatly enhance the agricultural productivity. As the loss of farmland property right, particularly the loss of farmland use right and the right to dispose of farm income, agricultural co-operation decreased the enthusiasm of farmers on production, led to a significant 
reduction in agricultural productivity. Since regaining the right to operate farmland and dispose agricultural income, farmers were re-ignited passion of production, the household responsibility system made a huge increase in agricultural productivity. All these show the performances of different institutional arrangements.

As economic theory states that equity and efficiency is often contradictory, but sometimes can have both. The 60 years of evolution of arrangements for farmland system in China also confirmed this. Land reform and the household responsibility system made farmers to obtain farmand right equally, it is also realized the tremendous increase in agricultural productivity. Policy goals of equity and efficiency synchronized. In agricultural cooperation period, the farmers had no farmland property right or use right, although it achieved near-absolute equity, it is precisely because the loss of farmland property right, it resulted in the loss of enthusiasm for production, led to a very low productivity. Efficient lost in the pursuit of equity.

The early stages of the family responsibility system achieved a win-win situation of equity and efficience, but later also showed the lack of efficiency. The policy of transfer of farmland use right compensated for this defect. However, with the incidence of litigation cases of the transfer of farmland use right in China, the current legal system is still protecting the original contractor to access farmland use right to ensure equity.

China's reform and opening up policy establishes the principle of "Giving priority to efficiency with the consideration to equity" of socialist market economic system. However, in the field of agriculture, the princple is "Giving priority to equity with the consideration to efficiency" since the founding of the PRC and never changed. This is decided by the nature of the China's socialist state and economic development stage. The industrialization catch up policy at the beginning of the PRC decided the subordinate status of agriculture in national economy, under the dual economic structure, the development of agriculture has to make sacrifices for the industry. As Schultz said that the developing countries in the "food problem" stage is necessary to the exploitation of agriculture and also maintain social stability, then almost totally equity system of property right arrangements for farmland in China becomes inevitable. With economic development, the economy accessed to middle-income stage, the "food problem" evolved to "poverty problem", how to improve the income of the farmers became increasingly important policy issue (Hayami, 2002). Due to the economic level increasing, Chinese government began to take agricultural subsidies policy, established rural social security system. But face of the huge rural population, these subsidies appear inadequate and can not change the status of living poverty of the peasants. Promote the land use right transfer to improve agricultural productivity, to a certain extent, to improve the income of farmers has become a policy option. On the other hand, China's economy has not completely out from the dual economic structure, agriculture is still needed to continue to provide cheap agricultural products for industrial develop- ment, equitable and stable social environment in rural areas is still needed for social development. So at it is not difficult to understant that the farmland institutional arrangements at this stage in China are based on the trade-off between equity and efficiency.

Can be expected, as China's further economic growth, a sound social security system in rural areas will be established. Farmers' stable income outside agriculture will increase. Farmland system as a function of social security and unemployment insurance will be further weakened. The policy objectives of the farmland system will change from "Giving priority to equity with the consideration to efficiency" to "Giving priority to efficiency with the consideration to equity". But this requires a long time.

\section{ACKNOWLEDGEMENT}

We appreciate Mr. Zhang Xiaohe for providing the transfer of farm land use right court cases. This research was financed by Shanghai Ocean University Doctoral Fellow Project No. A-2400-09-0154.

\section{REFERENCES}

Chen, T. and M. Yabe 2009 Study on the Formation of Household Management in Chinese Agriculture, Sci. Bull. Fac. Agr., Kyushu Univ. Volume 64: 63-73 (in Japanese)

Chen, Z. 2010 Chen Zhiwu Speaks China Economy. Shanxi Economics Press, Shanxi China (in Chinese)

China's Rural Land System Research Group (2006). Use Right of Farmland in Transfer: Equity vs. Efficiency. Issues in Agricultural Economy, 9: 9-12 (in Chinese)

Chinese Ministry of Agriculture 1996 China Agricultural Development Report 1995. China Agriculture Press, Beijing (in Chinese)

Fan, S. 1991 Effects of Technological Change and Institutional Reform on Production Growth in Chinese Agriculture. American Journal of Agricultural Economics, 73: 266-275

General Project Group of Development Research Institute 1988 China's Development: Wealth Growth and Institution Effect. Economics Research Journal, 5: 28-42 (in Chinese)

Hayami, y. and Y. Godo 2002 Agricultural Economics. Iwanami Syouten Press, Tokyo (in Japanese)

Jia, S., C. Tian and Q. Shi 2003 the Development Pattern and Policy Research of Farmland Use Right Market in East China. China Agriculture Press, Beijing (in Chinese)

Jin, S. and D. Klaus 2004 Land Rental Markets as an Alternative to Reallocation? Equity and Efficiency Considerations in the Chinese Land Tenure System. China Economics Quarterly, Vol. 3. No. 4: 1003-1027 (in Chinese)

Klaus, D. 2003 Land Policy for Growth and Poverty Reduction, The international Bank for Reconstruction and Development/ The World Bank, Washington, DC

Liu, R. 2010 Analysis of the Evolution of Framland Property Right System of the PRC in 60 Years. Productivity Research, 8: 26-28 (in Chinese)

Lin, Y. 1992 the System, Technology and Agricultural Development in China. Shanghai Sanlian Press, Shanghai (in Chinese)

McMillan, J., Whalley, J., and Zhu, L. 1989 the Impact of China'S Economic Reforms on Agricultural Productivity Growth. Journal of Political Economy, 97: 781-807

Qi, Z. and J. Shi 2007 the Land Contractual Use Right and the Role Of Performance-Four Court Cases as an Example. China Rural Survey, 2: 38-45 (in Chinese)

Qi, Z. and J. Shi 2008 Empirical Study on the Disputes for the 
Transfer of Contracted Land Management Righttarting from 9 Litigation Cases. Issues in agricultural economy, 1: 80-84 (in Chinese)

Song, M, T. Chen and L. Liu 2008 Economic Analysis of Land Institutions in China. China Agriculture Press, Beijing (in Chinese)

Tian, C. 2005 Farmland System, Farmland Rental Markets and Farmland Allocation Efficiency: Theory and The Experiences from Jiangsu, Zhejiang and Shandong Area. Economic Science Press, Beijing (in Chinese)

Ye, J. 2006 China Rural Land Market Survey-Based on 2005 Survey of 17 Provinces. China Rural Survey, 48-55 (in Chinese)

Yu, F. 2011 the International Status and Development Gap of
China's Economy, http://www.stats.gov.cn/was40/gitjj_detail.js p? searchword=GDP\&channelid $=6697 \&$ record $=16$ (in Chinese)

Zan, H. 2008 Research of the Determinants and Impact Farmland Use Right Transfer. PhD thesis (in Chinese)

Zhang, D. and L. Wan 2007 Study on Determinants of Contracted Farmland Use Right-Based on 15 Provinces (Regions) Investigation in 2004. Chinese Rural Economy, 2: 24-34 (in Chinese)

Zhang, H. 2002 Evolution of Land System in Rural China. China Agriculture Press, Beijing (in Chinese)

Zhao, Q. and Z. Tang 2008 Empirical Study on Status of Farmland Transfer and Farmers' Choice of Farmland Transfer Contract-Case Study of Mianzhu City, Sichuan Province. China Rural Survey, 3: 13-19 (in Chinese) 